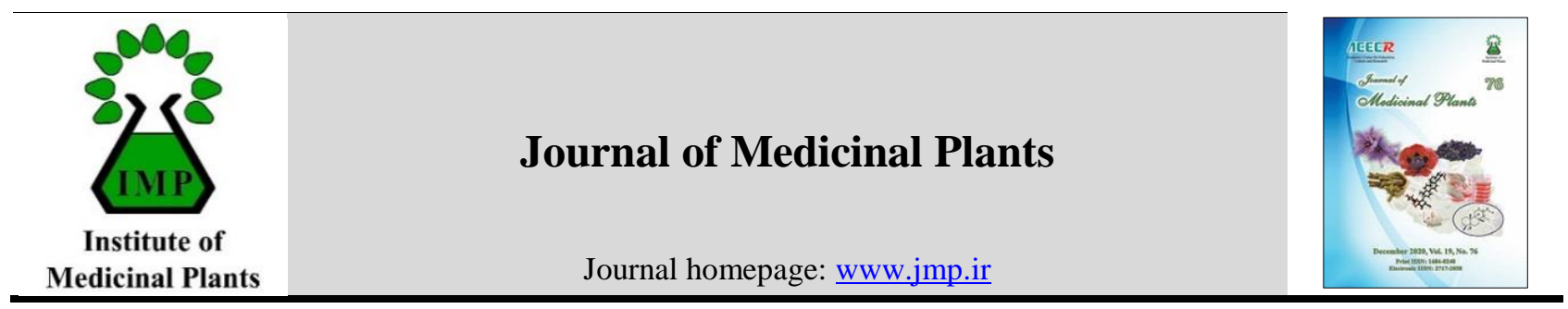

Review Article

\title{
A review of the genus Caesalpinia L.: emphasis on the cassane and norcassane compounds and cytotoxicity effects
}

\author{
Narges Pournaghi ${ }^{1}$, Farahnaz Khalighi-Sigaroodi ${ }^{1} *$, Elahe Safari ${ }^{2}$, Reza Hajiaghaee ${ }^{1}$ \\ ${ }^{1}$ Medicinal Plants Research Center, Institute of Medicinal Plants, ACECR, Karaj, Iran \\ ${ }^{2}$ Immunology Department, School of Medicine, Iran University of Medical Sciences, Tehran, Iran
}

\begin{tabular}{|c|c|}
\hline ARTICLE INFO & Abstract \\
\hline $\begin{array}{l}\text { Keywords: } \\
\text { Caesalpinia genus } \\
\text { Diterpenes } \\
\text { Cassane } \\
\text { Norcassane } \\
\text { Cytotoxic }\end{array}$ & $\begin{array}{l}\text { Background: Many herbal remedies have been used in medical systems for the } \\
\text { cure of diseases. One of these important applications is usage of them as cytotoxic } \\
\text { agents for the treatment of cancers and tumors. Various studies have been } \\
\text { conducted on several species of Caesalpinia genus including evaluation of } \\
\text { antimicrobial, antitumor, anti-inflammatory, antipsoriatic, antidiabetic, } \\
\text { antioxidant, antibacterial, immunomodulatory and hypoglycemic activities. Some } \\
\text { reports have shown that these plants contain phytochemicals like polyphenols, } \\
\text { glycosides, terpenoids, saponins and flavonoids. Objective: The aim of this study } \\
\text { was to find species of the Caesalpinia genus containing diterpene compounds } \\
\text { with the structure cassane and norcassane with emphasis on cytotoxic properties. } \\
\text { Methods: In this study, keywords including Caesalpinia genus, cytotoxic and } \\
\text { anticancer effects, and cassane and norcassane compounds were searched in } \\
\text { Scopus and Science Direct databases. Results: Thirteen Caesalpinia species were } \\
\text { investigated for phytochemical composition and biological effects. Different plant } \\
\text { parts of the species including leaves, seeds, stems, roots and legumes contained } \\
\text { diterpenes. Among these species, the cytotoxic effects on different cancer cell } \\
\text { lines have been evaluated and some had significant cytotoxic effects. Conclusion: } \\
\text { Present study show that Caesalpinia genus has valuable cytotoxic activity but } \\
\text { further studies are needed to investigate the active components and their possible } \\
\text { development as new anticancer drugs. }\end{array}$ \\
\hline
\end{tabular}

\section{Introduction}

Plants have an important role in maintaining health and improving the quality of life for many years. Plants have natural products that can promote health and improve sickness. Today, plant research has increased and many documents have collected to show extensive potential of medicinal plants used in several traditional systems. A great deal of public interest is in the use of herbal remedies. Medicinal plants, derived natural extracts and isolated compounds have many biological

*Corresponding author: khalighi@imp.ac.ir

doi: 10.29252/jmp.19.76.1

Received 22 July 2019; Received in revised form 6 November 2019; Accepted 9 November 2019

(C) 2020. Open access. This article is distributed under the terms of the Creative Commons Attribution-NonCommercial 4.0 International License (https://creativecommons.org/licenses/by-nc/4.0/) 
activities. Cancer disease is the second cause of death all over the world. Cancer was responsible for nearly 9.6 million deaths in 2018. Globally, about 1 in 6 deaths is because of cancer. Approximately $70 \%$ of deaths from cancer occur in third world countries. One of the common method for identification of new compounds used in chemotherapy and inhibition cancer process is screening of plants and their second metabolites as cytotoxic agents. For example, several species of Leguminosae and Solanaceae family have been studied for their cytotoxic effects [1 - 6]. One of these plants is Caesalpinia genus which have more than 500 species. These species are mostly distributed in tropical or subtropical countries [7]. This genus belongs to Fabaceae (Caesalpiniaceae) family are evergreen trees and shrubs and are cultivated as ornamental plants [8]. These plants are known for their medicinal properties. The generic name regards the botanist, physician and philosopher Andrea Cesalpino (1519-1603) [9].

\section{Materials and Methods}

In this study, keywords including Caesalpinia genus, cytotoxic and anticancer effects, and cassane and norcassane compounds were searched in Scopus and Science Direct databases. This review article describes species of the Caesalpinia genus that have also been biologically evaluated. On the other hand, the cytotoxicity effects, which is mostly related to cassane and norcassane compounds, have been emphasized.

\section{Results}

In order to classify and present the obtained information, first the botanical description and distribution of the genus, then phytochemistry and different species of the Caesalpinia genus were discussed. Finally, the extracted compounds from each species and their structure were presented in the form of tables and figures.

\subsection{Botany}

\subsubsection{Classification of Caesalpinia genus}

Classification of Caesalpinia genus has mentioned in Table 1 [10].

Table 1. Classification of plant

\begin{tabular}{cc}
\hline Kingdom & Plantae (plants) \\
\hline Division & Magnoliophyta (Angiosperms) \\
Class & Magnoliopsida (Dicotyledons) \\
Subclass & Rosidae \\
Order & Fabales \\
Family & Caesalpiniaceae \\
Genus & Caesalpinia \\
\hline
\end{tabular}

\subsubsection{Botanical characters of order Fabales}

The Fabales is the order of dicotyledonous flowering plants. This order includes four families and 754 genus that Fabaceae is the main and important family. The obvious specification of this order is the multiplicity seed pod with seeds present in a row. Another specification is root coexistence with nitrogen-fixing bacteria that relief the plants growth on poor soils [11].

\subsubsection{Botanical characters of family Caesalpiniaceae}

The plants of Caesalpiniaceae family are perennial or annual, tree, shrub, climbing and very rarely herbaceous. Leaves are alternate and pinnate. Inflorescences are clustered, sideways or terminative. The flowers are bisexual, irregular, with two-way symmetry and often have five fused or free sepals. This plants have four or five sepals (free or contiguous), 5-10 stamens (free or continuously together in different ways), and the upper ovary. Fruits are in the form of pods with seeds that often are without endosperm [12].

December 2020, Vol. 19, No. 76: 1-20 


\subsubsection{Botanical characters of genus Caesalpinia}

Caesalpinia genus includes trees, shrubs or wooden climbing. Leaves are great and alternate. Stem is straightest, woody or climbing, branched, covered with prickles or without prickles Stipules have lobe or without lobe, by several sizes or without stipules. Calyx is 5 serration. Petals are circular, free, yellow or red. This genus has 5-10 stamens, free or connected, and few ovules. Ovary is without pedicel. Fruit is leathery hard and woody, several shapes, sometimes covered with prickles [13].

\subsection{Distribution}

The genus Caesalpinia that consists of an important source of bioactive substances, has more than 500 species. This genus distributed all over the world mainly in tropical or subtropical countries and Namibia and America worm areas. Many of these species are endemic. For example, $C$. echinata exists only in Brazil and C. pulcherima is native to Central America and India [7]. Caesalpinia bond exists in tropical countries (Pakistan and South \& Southeast of Iran) [13].

\subsection{Phytochemistry}

Plants belonging to the genus Caesalpinia have been shown to contain different classes of constituents such as polysaccharide, phenolic derivatives, saponins, flavonoids, terpenoids \& etc. but the most important compounds are cassane and norcassane diterpenes and cassane furanoditerpenes [14].

The word cassane derived from "Cassa". Cassa is the native name for Erythrophleum guineense, the source of a diterpene alkaloid, cassaine. When the biosynthetic rearrangement was occurred in the pimarane precursor, the natural cassane and norcassane diterpenes are produced. They are existed in several genera of
Fabaceae family particularly in Caesalpinia genus [14].

The basic cassane skeleton is a tricyclic diterpene which has an ethyl group at carbon-13 and a methyl group at carbon-14 position but norcassane has one carbon less from cassane either from carbon-17 or carbon-16 positions (Fig. 1) [14].
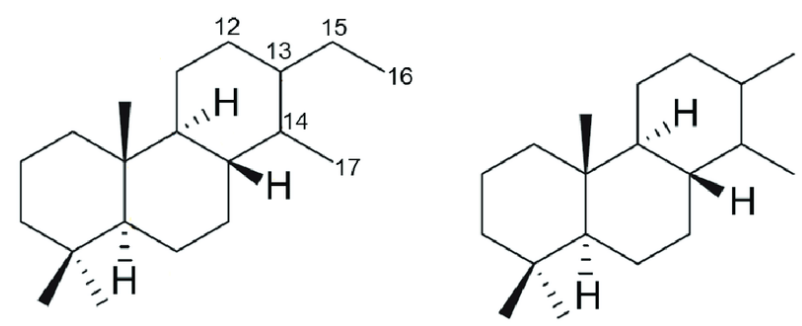

Fig. 1. Cassane (left) and norcassane (right) diterpenes skeleton

\subsection{Caesalpinia species}

3.4.1. Caesalpinia benthamiana (Baill.) Herend. \& Zarucchi

The petroleum extract of $C$. benthamiana root bark was studied and two cassane diterpenoids, benthaminin 1 and 2, and also, a deoxy form of caesaldekarin C (methyl vouacapenate), were isolated, together with $\beta$-sitosterol and stigmastenone. In this study, the antibacterial and antioxidant effects of $C$. benthamiana are also measured [15].

The name of Mezoneuron benthamianum Baill. is a synonym of Caesalpinia benthamiana (Baill.) Herend. \& Zarucchi. Previous studies on the leaves of this plant showed that methyl gallate and gallic acid are responsible for its antibacterial activity [16].

\subsubsection{Caesalpinia bonduc (L.) Roxb.}

In some references the name Caesalpinia bonduc and Caesalpinia bonducella are used as synonym [17]. Caesalpinia crista "L., p.p.A" is also a synonym of Caesalpinia bonduc (L.) Roxb [18]. Caesalls H-M (cassane diterpenoid) were 
isolated from the $\mathrm{CH}_{2} \mathrm{Cl}_{2}$ extract of $C$. bonduc seed kernel. The structures were identified by spectral and chemical methods. These compounds were not cytotoxic against MCF-7, HEP G2 and MG-63 cells [19]. In the other study, caesalls A-F, norcaesalpinin MC, caesalpinin D and bonducellpin were isolated from the ethanol extract of seed kernels of $C$. bonduc. The structures were characterized by NMR and mass spectroscopic data analyses. The cytotoxicity of all compounds were tested against MCF-7, HEP G2 and MG-63 cells. They showed weak inhibitory activities [20].

From the alkaline extract of the endosperm of seeds of $C$. bonduc, a gluco-arabinan was isolated [21]. Methanol extract of $C$. bonducella seed kernel was studied and bonducellpin $\mathrm{H}$, bonducellpin $\mathrm{I}$ and 7-acetoxycaesalpinin $\mathrm{P}$ (cassane-type furanoditerpenes) were isolated [22].

From the hexane extract of $C$. bonduc plant material, cassane diterpene hemiketals were isolated, caesalpinolide $\mathrm{C}$, caesalpinolide $\mathrm{D}$, caesalpinolide $\mathrm{E}$ and cassane furanoditerpene were isolated. The cytotoxicity of these compounds were tested against MCF-7, Du-145, $\mathrm{C} 33 \mathrm{~A}$ and Vero cell lines. They were shown a low to moderate activity [23].

The investigation on the ethanol extract of C. bonduc represented two new homoisoflavonoids, caesalpinianone and 6-Omethylcaesalpinianone with known compounds, stereochenol A, hematoxylol, 4'-O-acetylloganic acid, 6'-O-acetylloganic acid and 2-O- $\beta$-Dglucosyloxy-4-methoxybenzenepropanoic acid. These compounds were characterized by NMR and mass spectral studies. These compounds were shown glutathione S-transferase (GST) inhibitory and antifungal properties [24].

The leaves methanol extract of $C$. bonducella were studied for antitumor activity against
Ehrlich ascites carcinoma (EAC)-bearing Swiss albino mice. The results showed that this extract had remarkable antitumor activity in EACbearing mice by decreasing tumor volume, packed cell volume, and viable cell count [25].

Methanol extract of plant materials (legume, seed, aerial part) of $C$. bonduc were prepared and tested through the brine shrimp lethality assay to detect their cytotoxic effects. In comparing, the legume extract of $C$. bonduc showed significant cytotoxicity with $\mathrm{LC}_{50}$ value of $25.93 \mu \mathrm{g} / \mathrm{ml}$ [26].

In other researching, the plant materials (legume, seed and aerial part) of $C$. bonduc were extracted with methanol. Extracts were approved for their antiproliferative activity against Du-145 (prostate carcinoma) cancer cell line. Among the tested extracts, legume showed a better activity profile [27].

Another studies have proven antipsoriasis and increasing uterine smooth muscle contraction effects of leaves extract of C. bonduc [28, 29]. Antidiabetic and antimicrobial effects are also reported from different extracts of $C$. bonducella seeds [30, 31].

\subsubsection{Caesalpinia decapetala (Roth) Alston}

Decapetpene A, decapetpene B and decapetpene $\mathrm{C}$ were isolated from the EtOAc extract of $C$. decapetala seeds. The structure of these substances was identified by spectral data [32].

Two cassane diterpenes (caesaldecapes A\&B) were separated from the $\mathrm{CHCl}_{3}$ extract of C. decapetala seed by column chromatography and their structures were identified by NMR, MS, and HRESIMS. Caesaldecape A showed cytotoxic activity against KB cancer cell lines. An $\mathrm{IC}_{50}$ value was $9.6 \mu \mathrm{M}$ [33].

From the hexane and ethyl acetate extract of this plant roots, two cassane furanoditerpenoids, caesalacetal and caesalpinetate, and a 
norditerpenoid, caesalpinone were separated. The structures were identified by spectral data. The structure of caesalacetal was confirmed by $\mathrm{X}$-ray crystallographic analysis [34].

\subsubsection{Caesalpinia digyna Rottler}

Bergenin was isolated from $C$. digyna roots and was characterized by its melting point and spectroscopic data. Bergenin exhibits hypolipidemic, antidiabetic and antioxidant activity in type 2 diabetic rats [35].

\subsubsection{Caesalpinia echinata Lam.}

The acetone extract of the stem of $C$. echinata was studied and the echinalides A-G were isolated [36]. Also in further researching, the substances echinalides $\mathrm{H}-\mathrm{U}$ were isolated and the structures were elucidated by spectroscopic investigation [37]. These compounds showed anti-inflammatory activities [36, 37].

\subsubsection{Caesalpinia ferrea C.Mart.}

From the stems of $C$. ferrea, pauferrol A (a chalcone derivative), was isolated and the structure was determined by NMR spectroscopy. This new chalcone trimmer showed extensive inhibitory activity against human topoisomerase II, and cell proliferation inhibitory activity through the induction of apoptosis in human leukemia HL60 cells with an $\mathrm{IC}_{50} 5.2 \mu \mathrm{M}$ [38].

The polysaccharide galactomannan was isolated from the seed of $C$. ferrea and the experiments showed that this substance decreased hyperglycemia in diabetic rats and importantly lowered serum TAG (mediated effects on carbohydrate and lipid metabolism) [39].

Another researching was shown that the aqueous extract of $C$. ferrea stem bark reduced blood glucose levels and improved the metabolic state of the animals (STZ-diabetic rats) [40].
In other works, antiherpes, antitumor and cardiovascular effects of this plant were proved [41-44].

\subsubsection{Caesalpinia gilliesii (Hook.) D.Dietr.}

Hydroalcoholic (70 \%) extracts of leaves, flowers and pods of $C$. gilliesii were prepared and their cytotoxicity evaluated against five human tumor cell lines: HEP G2, MCF-7, HCT, HeLa and PC-3. The extract from flowers showed a powerful inhibition of cell growth in several cancer cell lines. A new $\beta$-sitosterol-3-O-butyl, a known sterol (daucosterol), and two flavonoids (isorhamnetin and isorhamnetin 3-O-rhamnoside) were isolated from dichloromethane fraction of flowers. $\beta$-Sitosterol-3-O-butyl was the most active compound against both MCF-7 and HEP G2 cells with $\mathrm{IC}_{50}$ values of 13.1 and $14.4 \mu \mathrm{g} / \mathrm{ml}$, respectively [45].

The methanol extract of $C$. gilliesii aerial parts was tested through the brine shrimp lethality assay to detect its cytotoxic effect. It showed cytotoxicity with $\mathrm{LC}_{50}$ value of $36.67 \mu \mathrm{g} / \mathrm{ml}$ [2].

\subsubsection{Caesalpinia mimosoides Lam.}

Caesmimosins A-F (cassane diterpenes) were isolated from the fruits of $C$. mimosoides. The structures of these compounds were identified by spectral data. The cytotoxicity of these compounds were studied on human cancer cell lines. They did not show cytotoxic activities at a concentration of $40 \mu \mathrm{M}$ [46].

The roots of $C$. mimosoides were extracted with $\mathrm{CH}_{2} \mathrm{Cl}_{2}$ and acetone at room temperature. Mimosol A-D (diterpene), mimosol E (dimmer), mimosol F-G (dibenzo [b,d] furans), taepeenin A, taepeenin D, taepeenin L, pterocarpol, bergenin, resveratrol, tetracosyl caffeate were isolated. Several of these compounds were examined for the inhibitory effect on LPSinduced tumor necrosis factor alpha (TNF- $\alpha)$ 
release in RAW264.7 cells. The results showed that mimosol $\mathrm{D}$ had extensive inhibitory activity with $\mathrm{IC}_{50} 6.5 \mu \mathrm{M}$ [47].

\subsubsection{Caesalpinia minax Hance}

Caesalmin $\mathrm{H}$ (cassane furanoditerpenoid), caesalmin $\mathrm{B}$ and bonducellpin D (furanoditerpenoid lactones) were isolated from the chloroform fraction of the seeds of $C$. minax and also friedelane triterpenoids, friedelin and epifriedelinol were isolated from the stems of this plant. These structures were identified by spectroscopic methods [48].

Four cassane diterpenes, caesalpines A-D were isolated from the ethyl acetate extract of C. minax seed. Their structures were elucidated by NMR and mass spectroscopy [49].

From the EtOAc extract of $C$. minax seed, neocaesalminin $\mathrm{A}$ and five furanoditerpenoids, caesalpinin $\mathrm{M}_{3}, \mathrm{M}_{4}, \mathrm{M}_{5}, \mathrm{~F}_{2}$ and $\mathrm{F}_{3}$ were isolated. Neocaesalminin A is a furanoditerpenoid with an unusual A-seco-rearranged cassane skeleton. Some of these compounds showed powerful inhibition of nitric oxide production of RAW264.7 macrophages stimulated by lipopolysaccharide (LPS) [50].

The investigations on the $\mathrm{CHCl}_{3}$ extract of C. minax seed afforded caesalpinin $\mathrm{M}_{1}$, caesalpinin $\mathrm{M}_{2}$, spirocaesalmin $\mathrm{B}$, caesalmin $\mathrm{E}_{1}$, caesalmin $E_{2}$, caesalmin $E_{3}$, caesalpinin $F_{1}$ (cassane furanoditerpenes). The structures were characterized by the spectroscopic analyses. These compounds showed moderate inhibitory activity on influenza virus neuraminidase (NA) in vitro [51].

Caesalminaxin $\mathrm{M}$ and caesalminaxin $\mathrm{N}$ were isolated from the $\mathrm{CHCl}_{3}$ extract of $C$. minax seed. Caesalminaxin $\mathrm{M}$ was the first example of dicylic cassane-type trinorditerpenoid. The structures were identified by NMR analysis. Caesalminaxin M showed moderate activity against K562 with
$\mathrm{IC}_{50}$ value of $18.4 \mu \mathrm{M}$ and $\mathrm{Du}-145$ with $\mathrm{IC}_{50}$ value of $35.0 \mu \mathrm{M}$ [52].

From the EtOAc extract of C. minax seeds, cassane diterpenes, sucutiniranes $\mathrm{G}, \mathrm{H}$ and I were isolated. Structures were identified by different spectral techniques. The cytotoxicity of all compounds were tested against MCF-7 and HEP G2. Sucutiniranes I showed mild antiproliferative activity against $\mathrm{MCF}-7$ with $\mathrm{IC}_{50}$ value of 21.4 and $\mathrm{HEP} \mathrm{G} 2$ with $\mathrm{IC}_{50}$ value of $35.6 \mu \mathrm{g} / \mathrm{ml}$. Sucutiniranes $\mathrm{G}$ and $\mathrm{H}$ did not show any antiproliferative activity [53].

The seeds of $C$. minax were extracted with methanol. The chloroform fraction was selected to silica gel column chromatography. Two diterpenes, norcaesalpinin I having an unusual ring C-contracted dinorcassane and caesalpinin $\mathrm{U}$ having a highly oxygenated furanocassane skeleton were isolated. The cytotoxic activity of these compounds was studied against HEP G2 and HeLa human cancer cell lines. The results showed that norcaesalpinin I had cytotoxic activity against $\mathrm{HEP} \mathrm{G} 2$ with $\mathrm{IC}_{50}$ value of 16.4 $\mu \mathrm{M}$ [54].

From the methanol extract of $C$. minax roots, caesalmins N-Q (cassane diterpenes) were isolated. The cytotoxicity of these compounds were tested against HEP G2, AGS and MCF-7 human cancer cell lines using the MTT method. These compounds was found to show weak cytotoxicity against cancer cell lines [55].

Another researching has investigated the antimalarial effects of diterpene alkaloids isolated from the seeds of $C$. minax [56].

\subsubsection{Caesalpinia platyloba S.Watson}

The dichloromethane extract from the leaves of C. platyloba was studied and six cassane diterpenes were isolated. The absolute configurations of all six diterpenes were established by comparison of DFT calculated 
vibrational circular dicroism spectra with those obtained experimentally [57].

\subsubsection{Caesalpinia pulcherrima (L.) Sw.}

The galactomannan from the seeds of C. pulcherrima was isolated and purified by ethanol and precipitation method [58].

From the dichloromethane extract of C. pulcherrima roots, 15 new cassane diterpenes were isolated. The compounds were named pulcherrins D-R. The structures of these compounds were identified by NMR and mass spectroscopy. Also, the anti-inflammatory activity of these compounds was investigated [59].

From the acetone extract of the aerial parts of C. pulcherrima, five flavonoids, 5,7-dimethoxy3',4'-methylenedioxyflavanone, cis-(Z)-7hydroxy-3-(4-methoxybenzylidine)-chroman-4one (isobonducellin), 5,7-dimethoxyflavanone, 2'-hydroxy-2,3,4',6'-tetramethoxychalcone and the homoisoflavonoid, bonducellin were isolated. The anti-inflammatory activity of isolated compounds was investigated [60].

\subsubsection{Caesalpinia sappan $\mathrm{L}$.}

The EtOAc fraction of heartwood of C. sappan was investigated and two new phenolic compounds, (3S,4R)-3,7, $2^{\prime}, 3^{\prime}$ tetrahydroxy-3,4-dihydro-9H-indeno[6,5-c] chromene (caesalpiniaphenol $\mathrm{E}$ ), and $(3 \mathrm{R}, 4 \mathrm{~S})$ 3,7-dihydroxy-3-(3'-methoxy-4'-hydroxyphenyl)4-methoxychroman (caesalpiniaphenol F), with brazilin, 3'-O-methyl brazilin, brazilane, 4'-Omethyl brazilin and protosappanin A were isolated. Among these compounds protosappanin A had potent inhibitory activities toward the LPS-induced NO production in macrophage RAW264.7 cells, with $\mathrm{IC}_{50} 12.5 \mu \mathrm{m}$ [61].

From the seed of $C$. sappan, two new rearranged diterpenoids, tomocinol $\mathrm{C}$ and spirocaesalmin $\mathrm{C}$ were isolated. Their structures were characterized by spectral data, and their absolute configurations were proved by single crystal X-ray crystallography [62].

Tomocins A-H, phanginin A, phanginin $\mathrm{F}$, phanginin $\mathrm{H}$, phanginin $\mathrm{K}$ and neocasalpinin $\mathrm{H}$ were isolated from the $\mathrm{CH}_{2} \mathrm{Cl}_{2}$ extract of the seed kernels of $C$. sappan L. [63]. In another work, tomocinon, tomocinol $\mathrm{A}$ and tomocinol $\mathrm{B}$ (cleistanthane diterpenes) were isolated from the EtOAc extract of the seed of C. sappan [64]. Tomocin A, phanginin A, F, H, tomocinon, tomocinol $\mathrm{A}$ and tomocinol $\mathrm{B}$ showed cytotoxicity against PANC-1 human pancreatic cancer cells $[63,64]$.

From the methanolic extract of the heartwood of C. sappan, a dimeric methanodibenzoxocinone, named neosappanone $\mathrm{A}$, was isolated and its structure was elucidated by spectroscopic analysis. The xanthine oxidase inhibitory activity of this plant from Vietnam to treat gout and related symptoms was investigated [65].

Brazilin was isolated from the EtOAc fraction of $C$. sappan wood. The antiproliferative activity of the methanolic extracts, fractions and isolated compound on HeLa cell line were investigated. Also, the antioxidative activities, total phenolic and flavonoid contents of the methanolic extract and fractions were verified. Brazilin, showed powerful antiproliferative activity with the $\mathrm{IC}_{50}$ value of $0.28 \mu \mathrm{g} / \mathrm{ml}$ which was higher than methanolic extract and EtOAc fraction [66].

The ethyl acetate fraction of $C$. sappan heartwood was studied and isoliquiritigenin $2^{\prime}$ methyl ether (ILME) was isolated. The effects of this compound on oral cancer cell lines were investigated by using fluorescence microscopy, MTT assays, Western blotting and flow cytometry. ILME inhibited the growth of the oral cancer cells in a time- and dose-dependent manner. Previously study was reported that a chloroform extract of $C$. sappan $\mathrm{L}$. induces apoptosis in oral cancer cells [67]. 
Two new cassane diterpenes, named phanginin $\mathrm{L}$ and phanginin $\mathrm{M}$, together with two known furanoditerpenoids, phanginin I and phanginin $\mathrm{G}$ were isolated from methanol extract of C. sappan seed. The cytotoxicity of these compounds were investigated using SF-268, MCF-7 and HEP G2 cell lines by the MTT assay. Phanginin L showed cytotoxicity against HEP $\mathrm{G} 2$ cell line with $\mathrm{IC}_{50}$ value of $9.13 \mu \mathrm{g} / \mathrm{ml}$ [68].

The chloroform fraction of the methanolic extract of $C$. sappan seeds was investigated and phanginins N-P (cassane furanoditerpenes) were yielded. All the compounds showed weak cytotoxicity against MCF-7, HEP G2 and HCT8 cancer cell lines [69].

Two biphenyl dimmers, caesappanin A and B, were isolated from the ethanolic extract of the $C$. sappan heartwood. Caesappanin A showed cytotoxicity against HCT-8, BGC-823, A549 and A2780 with IC $_{50}$ between $1.67 \mu \mathrm{M}$ and $4.88 \mu \mathrm{M}$. [70].

The heartwood of Lignum Sappan (C. sappan) was extracted with $95 \%$ ethanol. Then the ethyl acetate fraction was prepared from methanol extract. Three compounds, sappan chalcone, brazilin and butein were isolated. The influence of the ethyl acetate fraction and its components on growth-related signaling were appraised. The inhibitory effect on the cell cycle was tested by flow cytometric analysis. The results showed that C. sappan contains several active compounds with different anticancer activities. The ethyl acetate fraction was better than individual active constituent for the treatment of cancer [71].

From the $\mathrm{CH}_{2} \mathrm{Cl}_{2}$ extract of the $C$. sappan seeds, phanginin A-K were isolated. Phanginin I exhibited cytotoxicity against $\mathrm{KB}$ cell line with $\mathrm{IC}_{50}$ value of $4.4 \mu \mathrm{g} / \mathrm{ml}$ [72].

11-oxo-Phanginin A, caesalsappanins O-Q and phanginin $\mathrm{U}$ were isolated from chloroform extract of $C$. sappan seeds. All the new components exhibited moderate cytotoxicity on MCF-7 (human breast cancer) and HCT-116 (human colon cancer) cell lines [73].

From the C. sappan seeds, norcaesalpinin $\mathrm{J}$ and phangininoxys $\mathrm{B}$ and $\mathrm{C}$ (furanoditerpene) were isolated. Norcaesalpinin $\mathrm{J}$ has an unusual 20-norcassane hydroperoxide and phangininoxys $\mathrm{B}$ and $\mathrm{C}$ have cassane hemiketal skeletons. The cytotoxicity of these compounds was investigated against HEP G2, HCT-8 and MCF-7 by MTT method. Norcaesalpinin $\mathrm{J}$ showed cytotoxicity against all the tested cell lines, while phangininoxys $\mathrm{B}$ and $\mathrm{C}$ showed weak activity [74].

From the chloroform extract of the C. sappan seeds six new rearranged cassane- type diterpenes named as caesalppans A-F were isolated. The cytotoxic activity of the isolated compounds were tested against cancer cell lines using the MTT method. Caesalppans D showed better cytotoxic activity than others [75].

Two new protosappanins, named caesappin A and B were isolated from the ethyl acetate extract of C. sappan heartwood. Caesappin A has a seven-membered ring fusing an acetal-type section. Their cytotoxicity were investigated using MTT assay. Caesappin A showed moderate cytotoxicity against A549 cell line with $\mathrm{IC}_{50}$ value of $54.2 \mu \mathrm{M}$ [76].

Brazilein isolated from the heartwood of C. sappan, is a bioactive compounds that shows pharmacological effects such as antimicrobial, anti-oxidative, anti-inflammatory and antiatherosclerosis properties [77]. In two studies, the anticancer effects of $C$. sappan has been investigated and showed significant effect on the breast cancer cell lines [77, 78].

Also the anti-inflammatory activities of this plant have been studied in other investigations [79-81]. 


\subsubsection{Caesalpinia spinosa (Molina) Kuntze}

Six cassane diterpenes, isoneocaesalpin $\mathrm{H}$, caespinosin A-E were isolated from the twigs and leaves of Tara $(C$. spinosa). These cassane diterpenes were firstly reported from Tara. The cytotoxicity of these compounds were studied on HL-60, A-549, SMMC-7721, SW-480 and MCF7 human cancer cell lines, but they were not active [82].

From the $\mathrm{CHCl}_{3}$ extract of $C$. spinosa (Tara) pods, caesalpinone A was isolated. This compound is a new type of gorgonane sesquiterpenoid which has an unprecedented 1,15-bridge. The structure was identified by
NMR spectra. This compound was investigated for the inhibitory activities against five human cancer cell lines but no activity was shown [83].

In other work, the antibacterial and antioxidant effects of $C$. spinosa were investigated [84].

\section{Discussion}

As mention above, the Caesalpinia genus had several types of compounds and different pharmacological effects that were shown in Table 2 and 3. Because our emphasis is on the cytotoxicity effects, the compounds that have this effect were shown in Fig. 2.

Table 2. The compounds of the Caesalpinia species reported in the literature

\begin{tabular}{|c|c|c|}
\hline Plant & Plant parts & Compound \\
\hline \multirow{2}{*}{ C. benthamiana } & Leaves & Methyl gallate, Gallic acid [16] \\
\hline & Root bark & Benthaminines $1 \& 2$, Methyl vouacapenate, $\beta$-Sitosterol, Stigmastenone [15] \\
\hline \multirow{3}{*}{ C. bonduc } & Seed & $\begin{array}{l}\text { Caesalls H-M [19] } \\
\text { Caesalls A-F, Caesalpinin D, Bonducellpin D, Norcaesalpinin MC [20] } \\
\text { Gluco-arabinan [21] } \\
\text { Bonducellpin H\&I, 7-Acetoxycaesalpinin P [22] }\end{array}$ \\
\hline & Bark & $\begin{array}{l}\text { Caesalpinianone, 6-O-Methylcaesalpinianone, Hematoxylol, Stereochenol A, } \\
\text { 4'-O-Acetylloganic acid, 6'-O-Acetylloganic acid, 2-O- } \beta \text {-D-Glucosyloxy-4- } \\
\text { methoxybenzenepropanoic acid [24] }\end{array}$ \\
\hline & Plant material & $\begin{array}{l}\text { Caesalpinolides C-E, Friedelin, Lupeol, } \alpha \& \beta \text {-Amyrin, } \beta \text {-Sitosterol, } \\
\text { Stigmasterol [23] }\end{array}$ \\
\hline \multirow[t]{2}{*}{ C. decapetala } & Seed & $\begin{array}{l}\text { Decapetpenes A-C [32] } \\
\text { Caesaldecapes A \& B [33] }\end{array}$ \\
\hline & Root & Caesalacetal, Caesalpinetate, Caesalpinone [34] \\
\hline C. digyna & Root & Bergenin [35] \\
\hline C. echinata & Stem & $\begin{array}{l}\text { Echinalides A-G [36] } \\
\text { Echinalides H-U [37] }\end{array}$ \\
\hline \multirow{2}{*}{ C. ferrea } & Seed & Galactomannan [39] \\
\hline & Stem & Pauferrol A [38] \\
\hline C. gilliesii & Flower & $\begin{array}{l}\beta \text {-Sitosterol-3-O-butyl, Daucosterol, Isorhamnetin, Isorhamnetin 3-O- } \\
\text { rhamnoside [45] }\end{array}$ \\
\hline \multirow[b]{2}{*}{ C. mimosoides } & Fruit & Caesmimosins A-F [46] \\
\hline & Root & $\begin{array}{l}\text { Mimosols A-G, Taepeenins A, D \& L, Nortaepeenin A, Pterocarpol, } \\
\text { Bergenin, Resveratrol, Tetracosyl caffeate [47] }\end{array}$ \\
\hline
\end{tabular}


Table 2. The compounds of the Caesalpinia species reported in the literature (Continued)

\begin{tabular}{|c|c|c|}
\hline Plant & Plant parts & Compound \\
\hline \multirow[t]{3}{*}{ C. $\operatorname{minax}$} & Seed & $\begin{array}{l}\text { Caesalmins B \& H, Bonducellpin D [48] } \\
\text { Caesalpines A-D [49] } \\
\text { Neocaesalminin A, Caesalpinins } \mathrm{M}_{3}, \mathrm{M}_{4}, \mathrm{M}_{5}, \mathrm{~F}_{2} \& \mathrm{~F}_{3}[50] \\
\text { Spirocaesalmin B, Caesalpinins } \mathrm{M}_{1}, \mathrm{M}_{2}, \mathrm{E}_{1}, \mathrm{E}_{2}, \mathrm{E}_{3} \& \mathrm{~F}_{1} \text { [51] } \\
\text { Caesalminaxins M \& N [52] } \\
\text { Sucutiniranes G, H \& I [53] } \\
\text { Norcaesalpinin I, Caesalpinin U [54] }\end{array}$ \\
\hline & Stem & Friedelin, Epifriedelinol [48] \\
\hline & Root & Caesalmins N-Q [55] \\
\hline
\end{tabular}

\begin{tabular}{|c|c|c|}
\hline C. platyloba & Leaves & $\begin{array}{l}\text { (-)-(5S,6R,8S,9S,10R,14R)-6-Acetoxyvouacapane, } \\
\text { (-)-(5S,6R,8S,9S,10R,12Z,14R)-6-Acetoxycassa-12,15-diene, } \\
\text { (-)-(5S,6R,8S,9S,10R,13E)-6-Acetoxycassa-13,15-diene, } \\
\text { (-)-(5S,6R,8S,9S,10R,14R)-6-Hydroxyvouacapane, } \\
\text { (+)-(5S,8S,9S,10R,14R)-6-Oxovouacapane, } \\
\text { (+)-(5S,6S,8S,9S,10R,14R)-6-Acetoxyvouacapane [57] }\end{array}$ \\
\hline \multirow{3}{*}{ C. pulcherrima } & Seed & Galactomannan [58] \\
\hline & Root & Pulcherrins D-R [59] \\
\hline & Aerial parts & $\begin{array}{l}\text { 5,7-Dimethoxy-3',4'-methylenedioxyflavanone, Isobonducellin, } \\
\text { 5,7-Dimethoxyflavanone, Bonducellin, } \\
\text { 2'-Hydroxy-2,3,4',6'-tetramethoxychalcone [60] }\end{array}$ \\
\hline
\end{tabular}

\begin{tabular}{|c|c|c|}
\hline \multirow{3}{*}{ C. sappan } & Seed & $\begin{array}{l}\text { Tomocinol C, Spirocaesalmin C [62] } \\
\text { Tomocins A-H, Phanginins A, F, H \& K, Neocasalpinin H [63] } \\
\text { Tomocinon, Tomocinols A \& B [64] } \\
\text { Phanginins L, M, I \& G [68] } \\
\text { Phanginins N-P [69] } \\
\text { Phanginins A-K [72] } \\
\text { 11-oxo-Phanginin A, Caesalsappanins O-Q, Phanginin U [73] } \\
\text { Norcaesalpinin J, Phangininoxys B\&C [74] } \\
\text { Caesalppans A-F [75] }\end{array}$ \\
\hline & Heartwood & $\begin{array}{l}\text { Caesalpiniaphenols E \& F, Brazilin, 3'-O-Methyl brazilin, Brazilane, } \\
\text { 4'-O-methyl brazilin, Protosappanin A [61] } \\
\text { Neosappanone A [65] } \\
\text { Isoliquiritigenin 2'-methyl ether [67] } \\
\text { Caesappanin A and B [68, 70] } \\
\text { Sappan chalcone, Brazilin, Butein [71] } \\
\text { Caesappin A \& B [76] } \\
\text { Brazilein [77, 78] }\end{array}$ \\
\hline & Wood & Brazilin [66] \\
\hline \multirow{2}{*}{ C. spinosa } & $\begin{array}{l}\text { Twigs and } \\
\text { leaves }\end{array}$ & Isoneocaesalpin H, Caespinosins A-E [82] \\
\hline & Legume & Caesalpinone A [83] \\
\hline
\end{tabular}


Table 3. Pharmacological effects of Caesalpinia species

\begin{tabular}{|c|c|c|}
\hline Plant & Plant parts & Pharmacological effects \\
\hline \multirow{2}{*}{ C. benthamiana } & Leaves & Antibacterial [16] \\
\hline & Root bark & Antioxidant, Antibacterial [15] \\
\hline \multirow{5}{*}{ C. bonduc } & Seed & Antidiabetic, Antimicrobial $[30,31]$ \\
\hline & Legume & Cytotoxic $[26,27]$ \\
\hline & Leaves & Antipsoriasis, Increasing uterine smooth muscle contraction $[28,29]$ \\
\hline & Bark & Glutathione S-transferase inhibition, Antifungal [24] \\
\hline & Plant material & Cytotoxic [23] \\
\hline C. decapetala & Seed & Cytotoxic [33] \\
\hline C. digyna & Root & Antidiabetic, Hypolipidemic, Antioxidant [35] \\
\hline C. echinata & Stem & Anti-inflammation $[36,37]$ \\
\hline \multirow{3}{*}{ C. ferrea } & Seed & $\begin{array}{l}\text { Antidiabetic [39] } \\
\text { Antiherpes [41] } \\
\text { Antitumor [42, 43] }\end{array}$ \\
\hline & Stem & Cytotoxic [38] \\
\hline & Stem bark & $\begin{array}{l}\text { Antidiabetic [40] } \\
\text { Cardiovascular [44] }\end{array}$ \\
\hline \multirow{2}{*}{ C. gilliesii } & Flowers & Cytotoxic [45] \\
\hline & Aerial parts & Cytotoxic [2] \\
\hline C. mimosoides & Root & Inhibitory effect on LPS-induced tumor necrosis factor [47] \\
\hline C. minax & Seed & $\begin{array}{l}\text { Inhibitory activity on influenza virus neuraminidase (NA) [51] } \\
\text { Cytotoxic [52-54] } \\
\text { Antimalarial [56] }\end{array}$ \\
\hline \multirow{2}{*}{ C. pulcherrima } & Root & Anti-inflammatory [59] \\
\hline & Aerial parts & Anti-inflammatory [60] \\
\hline \multirow{3}{*}{ C. sappan } & Seed & Cytotoxic $[63,64,68,72-75]$ \\
\hline & Heart wood & $\begin{array}{l}\text { Cytotoxic [67, 70, 71, 76, 77] } \\
\text { Antimicrobial, Antioxidant, Anti-atherosclerosis [77] } \\
\text { Anti-inflammatory [77, 79-81] }\end{array}$ \\
\hline & Wood & Cytotoxic [66] \\
\hline C. spinosa & Legume & Antibacterial[84] \\
\hline
\end{tabular}




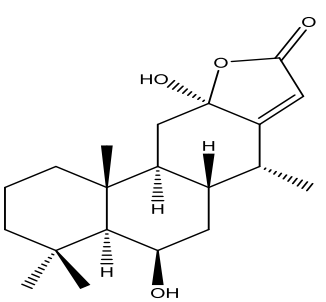

Caesalpinolide C [23]

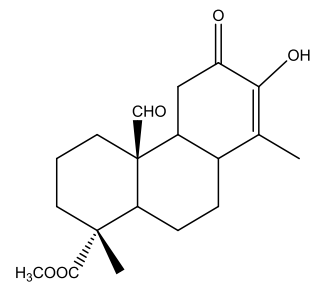

Caesaldecapes A [33]

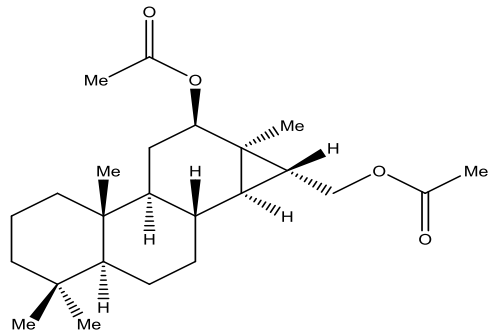

Mimosol D [47]

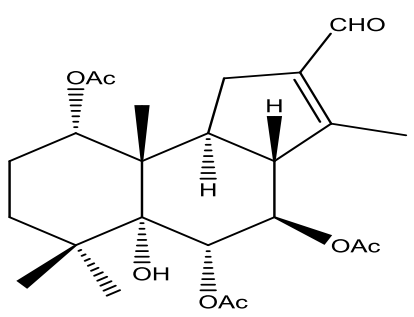

Norcaesalpinin I [54]

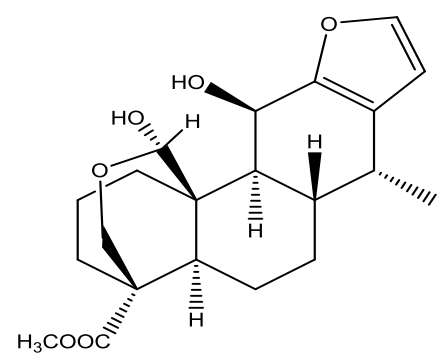

Phanginin F [63]

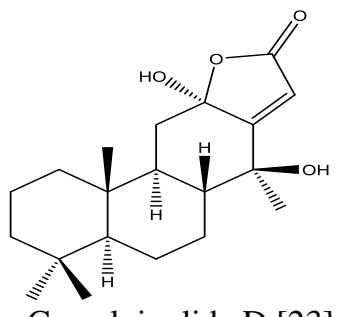

Caesalpinolide D [23]

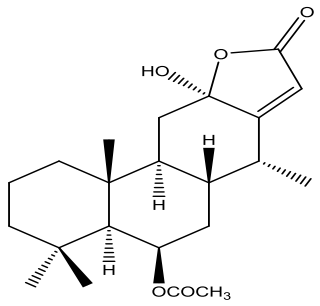

Caesalpinolide E [23]

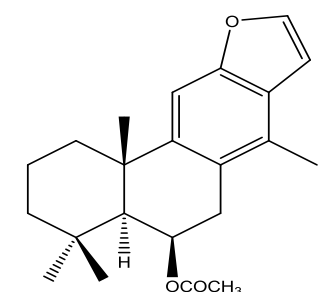

Cassane furanoditerpene [23]

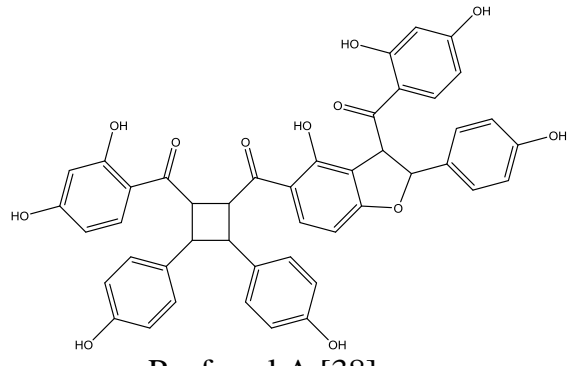

Pauferrol A [38]

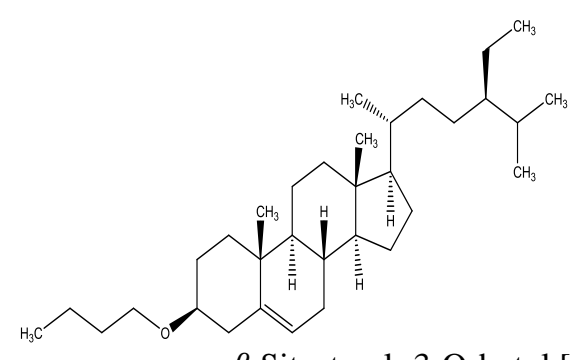

$\beta$-Sitosterol- 3-O-butyl [45]

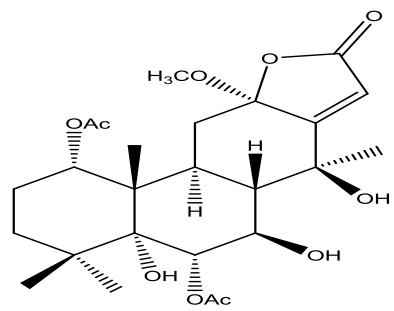

Sucutinirane I [53]

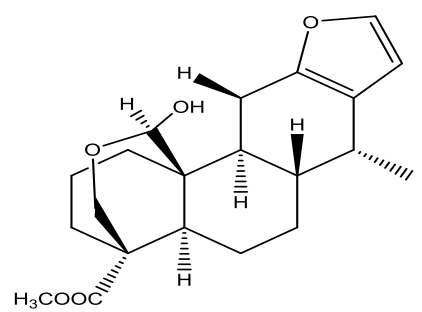

Phanginin A [63]

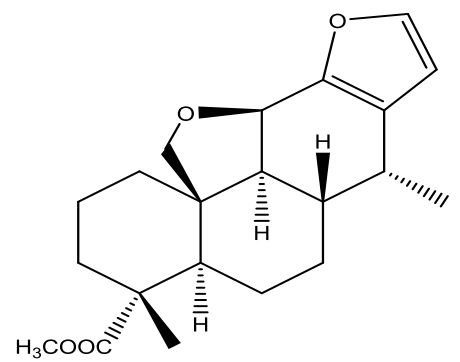

Phanginin H [63]

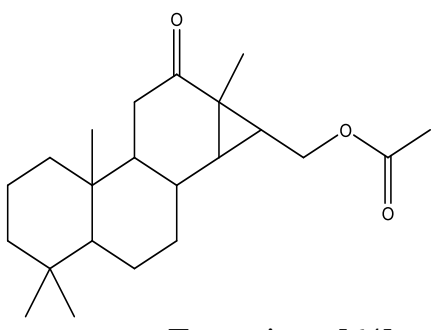

Tomocinon [64]

Fig. 2. Isolated compounds from Caesalpinia species with cytotoxic effects 
<smiles>CC(=O)OCC1C2C3CCC4C(C)(C)CCCC4(C)C3CC(O)C12C</smiles>

Tomocinol A [64]

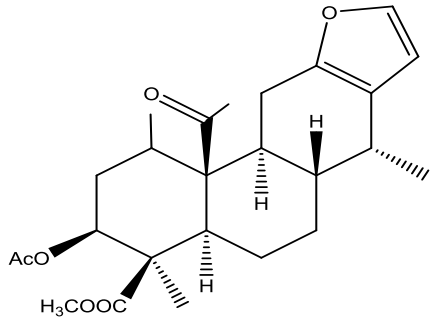

Phanginin L [68]<smiles>O=C(/C=C/c1ccc(O)c(O)c1)c1ccc(O)cc1O</smiles>

Butein [71]

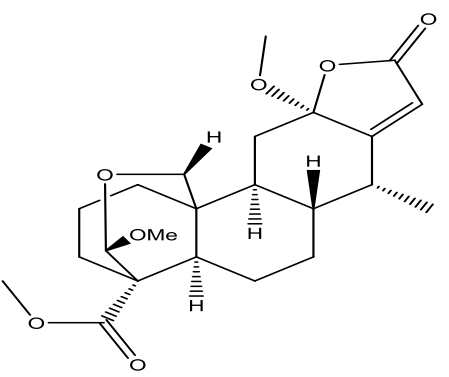

Caesalsappanin O [73]

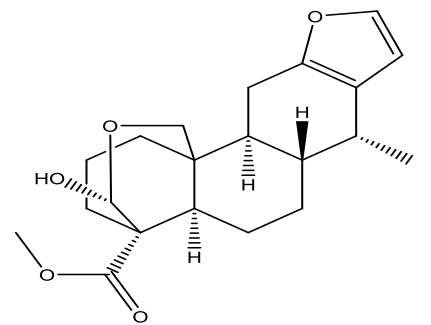

Phanginin U [73]<smiles>CC1(C)CCCC2(C)C3CC(O)C4(C)C(CO)C4C3CCC12</smiles>

Tomocinol B [64]<smiles>COc1cc(O)ccc1C(=O)/C=C/c1ccc(O)c(O)c1</smiles>

Caesappanin A [70]

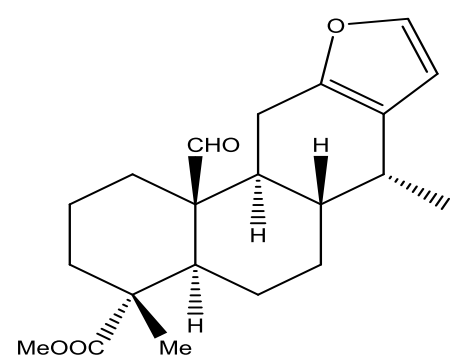

Phanginin I [72]
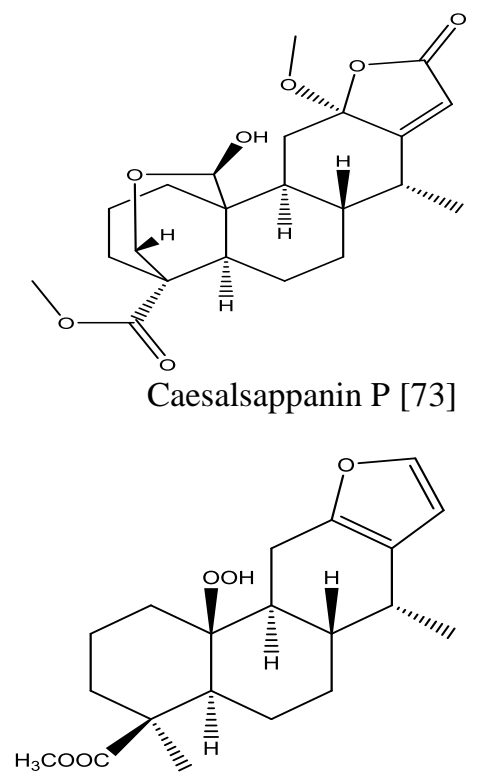

Norcaesalpinin J [74]
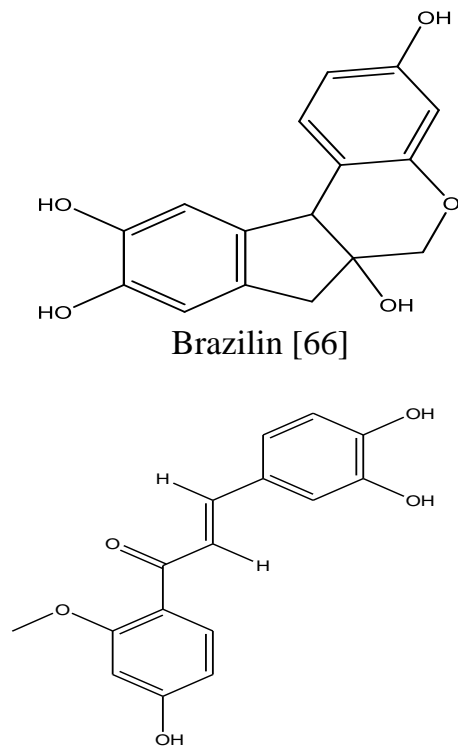

Sappan chalcone [71]

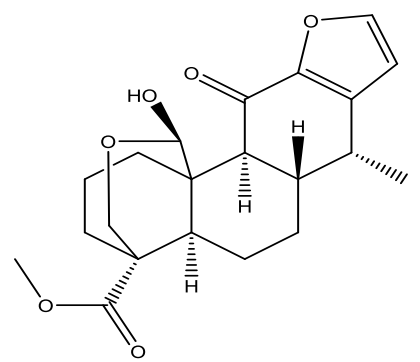

11-oxo-phanginin A [73]
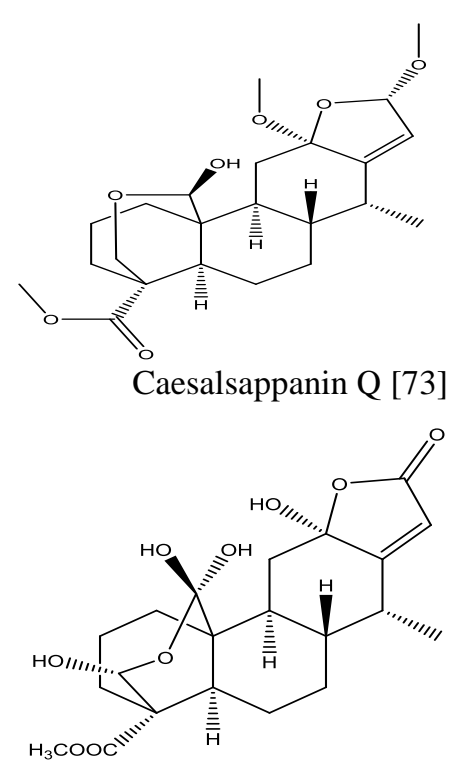

Caesalppan D [75]

Fig. 2. Isolated compounds from Caesalpinia species with cytotoxic effects (Continued) 


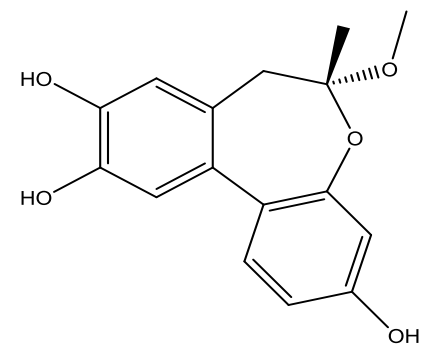

Caesappin A [76]

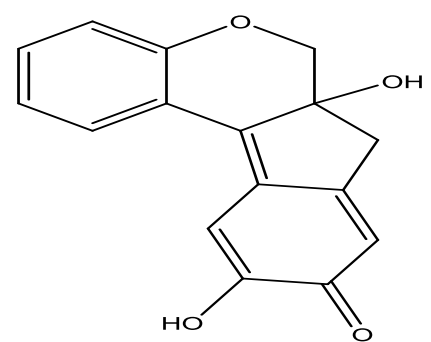

Brazilein [77]

Fig. 2. Isolated compounds from Caesalpinia species with cytotoxic effects (Continued)

\section{Conclusion}

The genus of Caesalpinia has more than 500 species. These are mainly distributed in tropical or subtropical countries. This genus belongs to Fabaceae family. They are evergreen trees and shrubs and are cultivated as ornamental plants. The genus of Caesalpinia has been shown to contain different classes of constituents such as polysaccharide, phenolic derivatives, saponins, flavonoids, terpenoids but the most important compounds are cassane and norcassane diterpenes and cassane furanoditerpenes. Different plant species of this genus have important pharmacological effects including antioxidant, antibacterial, antifungal, antiviral, antimalarial, antipsoriasis, increasing uterine smooth muscle contraction, antidiabetic, hypolipidemic, anti-inflammatory, antiherpes, cardiovascular effects, and also inhibitory effect on LPS-induced tumor necrosis factor and treat

\section{References}

1. Khalighi-Sigaroodi F, Hadjiakhoondi A, Ahvazi M, Taghizadeh M, Yazdani D and Khalighi-Sigaroodi Sh. Cytotoxicity screening of twenty three species of Iranian Leguminosae. $3^{r d}$ Congress of Medicinal Plants, Shahed University, 24 \& 25 October 2007, Tehran, Iran. 2. Khalighi-Sigaroodi F, Ahvazi M, Hadjiakhoondi A, Taghizadeh M, Yazdani D, Khalighi-Sigaroodi S and Bidel S. Cytotoxicity gout. The main biological effects of this genus is cytotoxic and antitumor properties.

In conclusion, the present study provide preliminary data about Caesalpinia genus to have cytotoxic activity. Further studies are needed to investigate the active components and their possible development as new anticancer drugs.

\section{Author contributions}

Narges Pournaghi and Farahnaz KhalighiSigaroodi collaborated in searching for content, collecting the articles and writing the manuscript. Elahe Safari and Reza Hajiaghaee collaborated in editing the article.

\section{Conflict of interest}

The authors declare that there is no conflict of interest.

and antioxidant activity of 23 plant species of Leguminosae family. IJPR 2012; 11(1): 295-302. 3. Khalighi-Sigaroodi F, Jeddi-Tehrani $M$, Ahvazi M, Shahnazi S, Bayat AA, Mohajer N and Zarei S. Cytotoxicity evaluation of two plant species from Leguminosae family on human cancer cell lines. $2^{\text {nd }}$ National Congress of Medicinal Plants, National Network of Research and Technology in Medicinal Plants, 15 \& 16 May 2013, Tehran, Iran. 
4. Khalighi-Sigaroodi F, Jeddi-Tehrani M, Ahvazi M, Shahnazi S, Bayat AA, Mohajer N and Zarei S. Cytotoxicity evaluation of Taverniera spartea on human cancer cell lines. $J$. Medicinal Plants 2014; 13(50): 114-128.

5. Khalighi-Sigaroodi F, Hadjiakhoondi A, Ahvazi M, Taghizadeh M, Yazdani D and Khalighi-Sigaroodi Sh. Brine shrimp toxicity of five species of Iranian Solanaceae. $3^{\text {rd }}$ Congress of Medicinal Plants, Shahed University, 24\&25October 2007, Tehran, Iran.

6. Khalighi-Sigaroodi F, Ahvazi M, Yazdani D and Kashefi M. Cytotoxicity and antioxidant activity of five plant species of Solanaceae family from Iran. J. Medicinal Plants 2012; 11(43): 41-53.

7. Zanin JLB, de Carvalho BA, Martineli PS, dos Santos MH, Lago JHG, Sartorelli P, Viegas C Jr and Soares MG. The genus Caesalpinia L. (Caesalpiniaceae): phytochemical and pharmacological characteristics. Molecules 2012; 17: 7887-7902.

8. Das B, Srinivas Y, Sudhakar C, Mahender I, Laxminarayana K, Reddy PR, Raju TV, Jakka NM and Rao JV. New diterpenoids from Caesalpinia species and their cytotoxic activity. Bioorg. Med. Chem. Lett. 2010; 20(9): 28472850.

9. Gledhill D. The Names of Plants. $4^{\text {th }}$ ed. Cambridge University Press. UK. 2008, p: 83.

10. Mozaffarian V. Plant taxonomy, first book: morphology-taxonomy. Amir-Kabir Press. Tehran. 2004, pp: 254-258.

11. The Angiosperm Phylogeny Group. An update of the Angiosperm Phylogeny Group classification for the orders and families of flowering plants: APG III. Bot. J. Linn. Soc. 2009; 161(2): 105-121.

Journal of Medicinal Plants
12. Mozaffarian V. Plant taxonomy, second book: dicotyledones. Amir-Kabir Press. Tehran. 2004, pp: 238-240.

13. Ghahremaninejad F. Flora of Iran. Research Institute of Forests and Rangelands. 2004; 45, pp: 3-7.

14. Maurya R, Ravi M, Singh S and Yadav PP. A review on cassane and norcassane diterpenes and their pharmacological studies. Fitoterapia 2012; 83: 272-280.

15. Dickson RA, Houghton PJ and Hylands PJ. Antibacterial and antioxidant cassane diterpenoids from Caesalpinia benthamiana. Phytochemistry 2007; 68: 1436-1441.

16. Binutu OA and Cordell GA. Gallic acid derivatives from Mezoneuron benthamianum leaves. Pharm. Biol. 2000; 38(4): 284-286.

17. Mozaffarian V. Identification of medicinal and aromatic plants of Iran. Farhang Moaser. Tehran. 2013, p: 89.

18. The Plant List. Version 1.1. Published on the Internet; http://www.theplantlist.org/ (accessed 1st January 2013).

19. Wu L, Wang X, Shan S, Luo J and Kong L. New cassane-type diterpenoids from Caesalpinia bonduc. Chem. Pharm. Bull. 2014; 62(7): 729733.

20. Wu L, Luo J, Zhang Y, Wang X, Yang L and Kong L. Cassane-type diterpenoids from the seed kernels of Caesalpinia bonduc. Fitoterapia 2014; 93: 201-208.

21. Mandal EK, Mandal S, Maity S, Behera B, Maiti TK and Islam SS. Structural studies of an immunostimulating gluco-arabinan from seeds of Caesalpinia bonduc. Carbohyd. polym. 2013; 92: 704-711.

22. Dang PH, Nguyen MTT, Nguyen HX, Vu DTT, Truong SV and Nguyen NT. Three new 
cassane-type furanoditerpenes from the seed of Vietnamese Caesalpinia bonducella. Phytochem. Lett. 2015; 13: 99-102.

23. Yadav PP, Maurya R, Sarkar J, Arora A, Kanojiya S, Sinha S, Srivastava $M N$ and Raghubir R. Cassane diterpenes from Caesalpinia bonduc. Phytochemistry 2009; 70(2): 256-261.

24. Ata A, Gale EM and Samarasekera R. Bioactive chemical constituents of Caesalpinia bonduc (Fabaceae). Phytochem. Lett.2009; 2(3): 106-109.

25. Gupta M, Mazumder Uk, Kumar RS, Sivakumar T and Vamsi ML. Antitumor activity and antioxidant status of Caesalpinia bonducella against Ehrlich ascites carcinoma in Swiss albino mice. J Pharmacol Sci. 2004; 94(2): 177-184.

26. Khalighi-Sigaroodi F, Hadjiakhoondi A, Ahvazi M, Taghizadeh M, Yazdani D, KhalighiSigaroodi Sh. Cytotoxicity evaluation of two species from Caesalpinia genus. J. Medicinal Plants 2008; 7(25): 60-70.

27. Pournaghi N, Khalighi-Sigaroodi F, Safari E and Hajiaghaee R. Investigation of cytotoxicity effect of Caesalpinia bonduc on prostate cancer cell line. $7^{\text {th }}$ National Congress of Medicinal Plants, National Network of Research and Technology in Medicinal Plants, 12 \& 14 May 2018, Shiraz, Iran.

28. Muruganantham N, Basavaraj KH, Dhanabal SP, Praveen TK, Shamasundar NM and Rao KS. Screening of Caesalpinia bonduc leaves for antipsoriatic activity. J. Ethnopharmacol. 2011; 133(2): 897-901.

29. Datte JY, Traore A, Offoumou AM and Ziegler A. Effects of leaf extract of Caesalpinia bonduc (Caesalpiniaceae) on the contractile activity of uterine smooth muscle of pregnant rats. J. Ethnopharmacol. 1998; 60(2): 149-155.

30. Parameshwar S, Srinivasan KK and Mallikarjuna Rao C. Oral antidiabetic activities of different extracts of Caesalpinia bonducella seed kernels. Pharm. Biol. 2002; 40(8): 590-595. 31. Arif T, Mandal TK, Kumar N, Bhosale JD, Hole A, Sharma GL, Padhi MM, Lavekar GS and Dabur R. In vitro and in vivo antimicrobial activities of seeds of Caesalpinia bonduc Roxb. J. Ethnopharmacol. 2009; 123(1): 177-180.

32. Xu J, Cao X, Liu F, Ma J, Liu X, Tong L, Su G, Ohizumi Y, Lee D, Wang L and Guo Y. Characterization of diterpenoids from Caesalpinia decapetala and their anti-TMV activities. Fitoterapia 2016; 113: 144-150.

33. Ma GX, Chen P, Sun ZH, Zhu NL, Li PF, Yang JS, Chen DL and Wei H.Novel cassane diterpenes from the seeds of Caesalpinia decapetala and their antiproliferative activity. Phytochem. Lett. 2016; 16: 52-55.

34. Kamikawa S, Oshimo S, Ohta E, Nehira T, Omura $\mathrm{H}$ and Ohta S. Cassane diterpenoids from the roots of Caesalpinia decapetala var. japonica and structure revision of caesaljapin. Phytochemistry 2016; 121: 50-57.

35. Kumar R, Patel DK, Prasad SK, Laloo D, Krishnamurthy $\mathrm{S}$ and Hemalatha S. Type 2 antidiabetic activity of bergenin from the roots of Caesalpinia digyna Rottler. Fitoterapia 2012; 83(2): 395-401.

36. Mitsui T, Ishihara R, Hayashi K, Sunadome M, Matsuura N and Nozaki H. New cassane-type diterpenoids of Caesalpinia echinata (Leguminosae) exhibiting NF- $\mathrm{BB}$ inhibitory activities. Chem. Pharm. Bull. 2014; 62(3): 267273. 
37. Mitsui T, Ishihara R, Hayashi K, Matsuura N, Akashi $\mathrm{H}$ and Nozaki $\mathrm{H}$. Cassane-type diterpenoids from Caesalpinia echinata (Leguminosae) and their NF-jB signaling inhibition activities. Phytochemistry 2015; 116: 349-358.

38. Nozaki H, Hayashi K, Kido M, Kakumoto K, Ikeda S, Matsuura N, Tani H, Takaoka D, Iinuma $\mathrm{M}$ and Akao Y. Pauferrol A, a novel chalcone trimmer with a cyclobutane ring from Caesalpinia ferrea mart exhibiting DNA topoisomerase II inhibition and apoptosisinducing activity. Tetrahedron Lett. 2007; 48(47): 8290-8292.

39. Cunha AP, Ribeiro ACB, Ricardo NMPS, Oliveira AC, Davila LSP, Cardoso JHL, Rodrigues DC, Azeredo HMC, Silva LMA, Brito ES, Filho JM, Rocha TM, Leal LKAM and Ricardo NMPS. Polysaccharides from Caesalpinia ferrea seeds - Chemical characterization and anti-diabetic effects in Wistar rats. Food Hydrocolloid. 2017; 65: 68-76.

40. Vasconcelos CF, Maranhao HM, Batista TM, Carneiro EM, Ferreira F, Costa J, Soares LA, Sa MD, Souza TP and Wanderley AG. Hypoglycemic activity and molecular mechanisms of Caesalpinia ferrea Martius bark extract on streptozotocin-induced diabetes in Wistar rats. J. Ethnopharmacol. 2011; 137(3): 1533-1541.

41. Lopes N, Faccin-Galhardi LC, Espada SF, Pacheco AC, Ricardo NM, Linhares RE and Nozawa C. Sulfated polysaccharide of Caesalpinia ferrea inhibits simplex virus and poliovirus. Int. J. Biol. Macromol. 2013; 60: 9399.

42. Nakamuraa ES, Kurosakia F, Arisawa M, Mukainaka T, Okuda M, Tokuda H, Nishino H and Pastore F. Cancer chemo preventive effects of constituents of Caesalpinia ferrea and related compounds. Cancer Lett. 2002; 177(2): 119-124. 43. Nakamuraa ES, Kurosakia F, Arisawa M, Mukainaka T, Takayasu J, Okuda M, Tokuda H, Nishino $\mathrm{H}$ and Pastore $\mathrm{F}$. Cancer chemo preventive effects of Brazilian folk medicine, Juca, on in vivo two-stage skin carcinogenesis. $J$. Ethnopharmacol. 2002; 81(1): 135-137.

44. Menezes IA, Moreira IJ, Carvalho AA, Antoniolli AR and Santos MR. Cardiovascular effects of the aqueous extract from Caesalpinia ferrea: involvement of ATP-sensitive potassium channels. Vasc. Pharmacol. 2007; 47(1): 41-47.

45. Osman SM, Abd El-Khalik SM, El-Haddad $\mathrm{AE}$ and Wink M.A new steroidal compound ( $\beta$ sitosterol-3-O-butyl) isolated from Caesalpinia gilliesii flowers. IJARNP. 2015; 8(2): 14-19.

46. Bi D, Xia G, Liang X, Li Y, Zhang L and Wang L. New cassane diterpenes from the fruits of Caesalpinia mimosoides Lam. Phytochem. Lett. 2017; 21: 283-286.

47. Yodsaoue O, Karalai C, Ponglimanont C, Tewtrakul S and Chantrapromma S. Potential anti-inflammatory diterpenoids from the roots of Caesalpinia mimosoides Lamk. Phytochemistry 2010; 71(14-15): 1756-1764.

48. Jiang RW, Ma SC, He ZD, Huang XS, But PPH, Wang H, Chan SP, Ooi VEC, Xu HX and Mak TCW. Molecular structures and antiviral activities of naturally occurring and modified cassane furanoditerpenoids and friedelane triterpenoids from Caesalpinia minax. Bioorgan. Med. Chem. 2002; 10(7): 2161-2170.

49. Zhao $\mathrm{P}$, Chen $\mathrm{H}$, Wang $\mathrm{H}, \mathrm{Xu} \mathrm{J}$, Wang M, Wang Y, Jin DQ and Guo Y. Four new cassane diterpenes from the seeds of Caesalpinia minax. Phytochem. Lett. 2013; 6(4): 606-609. 
50. Dong R, Yuan J, Wu S, Huang J, Xu X, Wu $\mathrm{Z}$ and Gao H. Anti-inflammation furanoditerpenoids from Caesalpinia minax Hance. Phytochemistry 2015; 117: 325-331.

51. Wu J, Chen G, Xu X, Huo X, Wu S, Wu Z and Gao H. Seven new cassane furanoditerpenes from the seeds of Caesalpinia minax. Fitoterapia 2014; 92: 168-176.

52. Zheng $\mathrm{Y}$, Zhang SW and Xuan LJ. Trinorcassane and cassane diterpenoids from the seeds of Caesalpinia minax. Fitoterapia 2015; 102: 177-181.

53. Ma G, Yuan J, Wu H, Fang K, Yang J, Ma L and Xudong $\mathrm{X}$. Novel cassane diterpenes from the seeds of Caesalpinia minax. Phytochem. Lett. 2012; 5(3): 617-620.

54. Wu HF, Hong JY, Sun ZH, Yuan JQ, Wei H, Zhang XP, Tian Y, Zhu YD, Yang JS, Ma GX and Xu XD. Novel dinorcassane- and cassanetype diterpenes from the seeds of Caesalpinia minax. Fitoterapia 2014; 94: 172-176.

55. Li Q, He YN, Niu B, Wang XG, Niu LY and Feng W. Caesalmins N-Q, new cassane diterpenes from the seeds of Caesalpinia minax. Phytochem. Lett. 2016; 17: 23-27.

56. Ma G, Sun Z, Sun Z, Yuan J, Wei H, Yang J, $\mathrm{Wu} \mathrm{H}$ and $\mathrm{Xu} \mathrm{X}$. Antimalarial diterpene alkaloids from the seeds of Caesalpinia minax. Fitoterapia 2014; 95: 234-239.

57. Gomez-Hurtado MA, Alvarez-Esquivel FE, Rodríguez-Garcia G, Martinez-Pacheco MM, Espinoza-Madrigal RM, Pamatz-Bolanos T, Salvador-Hernandez JL, Garcia-Gutierrez HA, Cerda-Garcia-Rojas CM, Joseph-Nathan P and del Rio RE. Cassane diterpenes from Caesalpinia platyloba. Phytochemistry 2013; 96: 397-403.

58. Thombre NA and Gide PS. Rheological characterization of galactomannans extracted from seeds of Caesalpinia pulcherrima. Carbohyd. Polym. 2013; 94(1): 547-554.

59. Yodsaoue O, Karalai C, Ponglimanont C, Tewtrakul Sand Chantrapromma S. Pulcherrins D-R, potential anti-inflammatory diterpenoids from the roots of Caesalpinia pulcherrima. Tetrahedron 2011; 67(36): 6838-6846.

60. Rao YK, Fang SH and Tzeng YM. Antiinflammatory activities of flavonoids isolated from Caesalpinia pulcherrima. J. Ethnopharmacol. 2005; 100(3): 249-253.

61. Min BS, Cuong TD, Hung TM, Min BK, Shin BS and Woo MH. Compounds from the heartwood of Caesalpinia sappan and their antiinflammatory activity. Bioorg. Med. Chem. Lett. 2012; 22(24): 7436-7439.

62. Xiao F, Tang CP, Ke CQ, Yao Sand Ye Y. Rearranged diterpenoids from the seeds of Caesalpinia sappan. Chinese Chem. Lett. 2016; 27(12): 1751-1754.

63. Nguyen HX, Nguyen NT, Dang PH, Ho PT, Nguyen MTT, Can MV, Dibwe DF, Ueda JY and Awale S. Cassane diterpenes from the seed kernels of Caesalpinia sappan. Phytochemistry 2016; 122: 286-293.

64. Nguyen HX, Nguyen MTT, Nguyen TA, Nguyen NYT, Phan DAT, Thi PH, Nguyen THP, Dang PH, Nguyen NT, Ueda JY and Awale S. Cleistanthane diterpenes from the seed of Caesalpinia sappan and their antiausterity activity against PANC-1 human pancreatic cancer cell line. Fitoterapia 2013; 91: 148-153.

65. Nguyen MTT, Awale S, Tezuka Y, Tran QL and Kadota S. Neosappanone A, a xanthine oxidase (XO) inhibitory dimeric methanodibenzoxocinone with a new carbon skeleton from Caesalpinia sappan. Tetrahedron Lett. 2004; 45: 8519-8522. 
66. Kitdamrongtham W, Manosroi A, Akazawa H, Gidado A, Stienrut P, Manosroi W, Lohcharoenkal W, Akihisa $\mathrm{T}$ and Manosroi J. Potent anti-cervical cancer activity: synergistic effects of Thai medicinal plants in recipe N040 selected from the MANOSROI III database. $J$. Ethnopharmacol. 2013; 149(1): 288-296.

67. Lee YM, Jeong GS, Lim HD, An RB, Kim $\mathrm{YC}$ and Kim EC. Isoliquiritigenin 2'-methyl ether induces growth inhibition and apoptosis in oral cancer cells via heme oxygenase-1. Toxicol. In Vitro 2010; 24(3): 776-782.

68. Zhang JY, Wu FH, Qu Wand Liang JY. Two new cassane diterpenoids from the seeds of Caesalpinia sappan Linn. Chin. J. Nat. Medicines 2012; 10(3): 218-221.

69. Ma GX, Zhu YD, Sun ZH, Yuan JQ, Xie Y, Zhang XP, Tian Y, Yang JS, Wu HF and Xu XD. Three new cassane diterpenes from the seeds of Caesalpinia sappan. Phytochem. Lett. 2014; 8: 141-144.

70. Shu SH, Deng AJ, Li ZH and Qin HL. Two novel biphenyl dimmers from the heartwood of Caesalpinia sappan. Fitoterapia 2011; 82(5): 762-766.

71. Zhang Q, Liu JL, Qi XM, Qi CT and Yu Q. Inhibitory activities of Lignum Sappan extractives on growth and growth-related signaling of tumor cells. Chin. J. Nat. Medicines 2014; 12(8): 607-612.

72. Yodsaoue O, Cheenpracha S, Karalai C, Ponglimanont C, Chantrapromma S, Fun HK and Kanjana-Opas A. Phanginin A-K, diterpenoids from the seeds of Caesalpinia sappan Linn. Phytochemistry 2008; 69(5): 1242-1249.

73. Wu ZF, Bao H, Zhou FY, Liu JX, Meng FC, Feng L, Lu JJ, Zhang QW, Ye Y and Lin LG. Cytotoxic cassane diterpenoids from the seeds of
Caesalpinia sappan. Chinese Chem. Lett. 2017; 28(8): 1711-1715.

74. Wu HF, Zhu YD, Sun ZH, Yuan JQ, Wei H, Zhang XP, Tian Y, Yang JS, Ma GX and Xu XD. Norcassane- and cassane-type furanoditerpenoids from the seeds of Caesalpinia sappan. Fitoterapia 2014; 98: 22-26.

75. Xu X, Yuan J, Zhou X, Li W, Zhu N, Wu H, Li $\mathrm{P}$, Sun Z, Yang J and Ma G. Cassane diterpenes with oxygen bridge from the seeds of Caesalpinia sappan. Fitoterapia 2016; 112: 205-210.

76. Wang Z, Sun JB, Qu W, Guan FQ, Li LZ and Liang JY. Caesappin A and B, two novel protosappanins from Caesalpinia sappan $\mathrm{L}$. Fitoterapia 2014; 92: 280-284.

77. Tao LY, Li JY and Zhang JY. Brazilein, a compound isolated from Caesalpinia sappan Linn., induced growth inhibition in breast cancer cells via involvement of GSK-3 $\beta / \beta$ Catenin/cyclin D1 pathway. Chem-Biol. Interact. 2013; 206(1): 1-5.

78. Hsieh CY, Tsai PC, Chu CL, Chang FR, Chang LS, Wu YC and Lin SR. Brazilein suppresses migration and invasion of MDA-MB231 breast cancer cells. Chem-Biol. Interact. 2013; 204(2): 105-115.

79. Bae IK, Min HY, Han AR, Seo EK and Lee SK. Suppression of lipopolysaccharide-induced expression of inducible nitric oxide synthase by brazilin in RAW 264.7 macrophage cells. Eur. J. Pharmacol. 2005; 513(3): 237-242.

80. Shen J, Zhang H, Lin H, Su H, Xing D and $\mathrm{Du}$ L. Brazilein protects the brain against focal cerebral ischemia reperfusion injury correlating to inflammatory response suppression. Eur. J. Pharmacol. 2007; 558(1-3): 88-95.

81. Zeng KW, Yu Q, Song FJ, Liao LX, Zhao $\mathrm{MB}$, Dong $\mathrm{X}$, Jiang $\mathrm{Y}$ and $\mathrm{Tu} \mathrm{PF}$. 
Deoxysappanone B, a homoisoflavone from the Chinese medicinal plant Caesalpinia sappan L., protects neurons from microglia-mediated inflammatory injuries via inhibition of IкB kinas (IKK)-NF- $\kappa$ B and p38/ERK MAPK pathways. Eur. J. Pharmacol. 2015; 748: 18-29.

82. He D, Li Y, Tang H, Ma R, Li X and Wang L. Six new cassane diterpenes from the twigs and leaves of Tara (Caesalpinia spinosa Kuntze). Fitoterapia 2015; 105: 273-277.

83. Mu W, Tang H, Li Y, He D, Ma Rand Wang L. Caesalpinone A, a new type of gorgonane sesquiterpenoid containing an unprecedented 1,15-bridge, from the pods of Caesalpinia spinosa Kuntze. Fitoterapia 2016; 112: 233-236.
84. Aguilar-Galves A, Noratto G, Chambi F, Debaste $\mathrm{F}$ and Campos D. Potential of tara (Caesalpinia spinosa) gallotannins and hydrolysates as natural antibacterial compounds. Food Chem. 2014; 156: 301-304.

How to cite this article: Pournaghi N, Khalighi-Sigaroodi F, Safari E, Hajiaghaee R. A review of the genus Caesalpinia L.: emphasis on the cassane and norcassane compounds and cytotoxicity effects. Journal of Medicinal Plants 2020; 19(76): 1-20. doi: 10.29252/jmp.19.76.1 


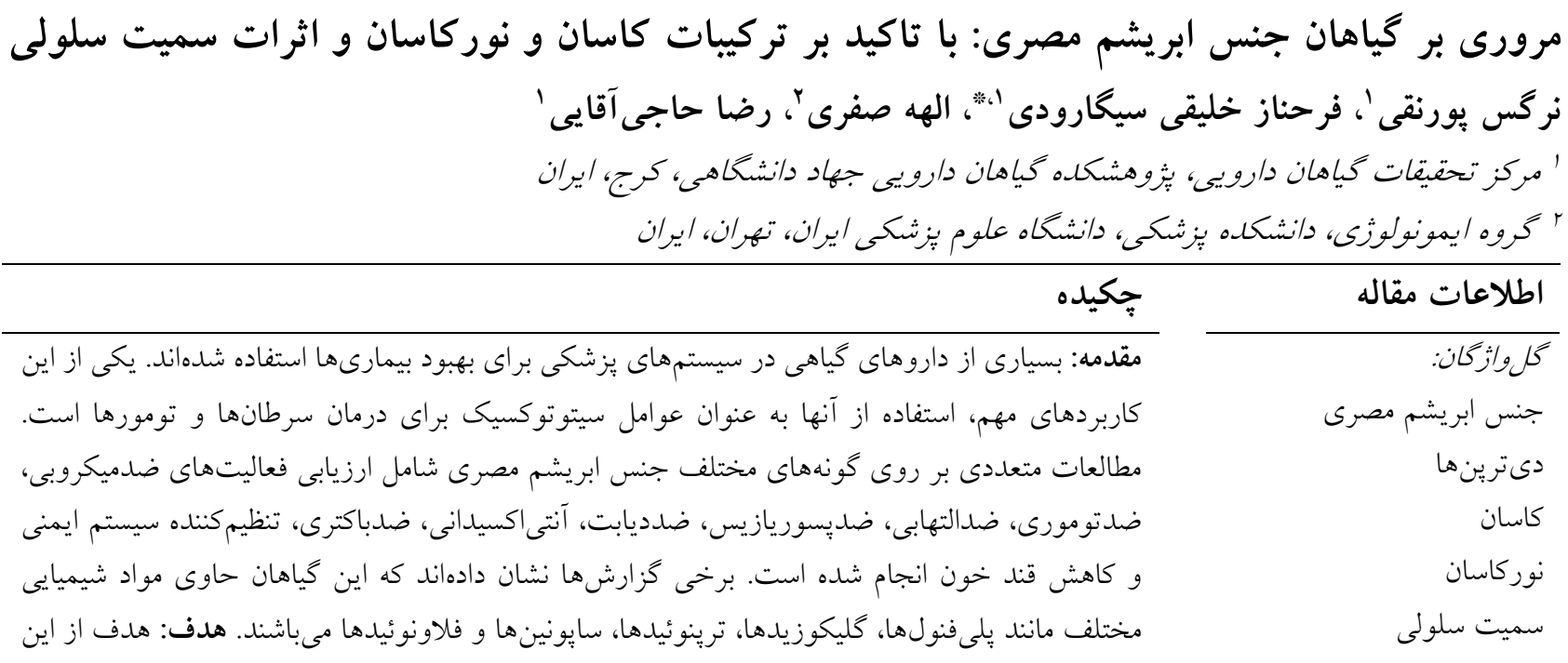

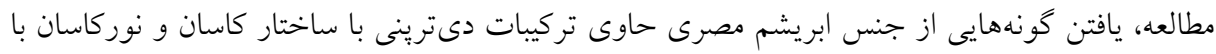

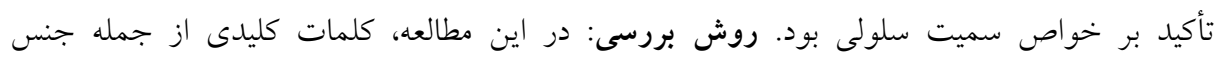
Caesalpinia

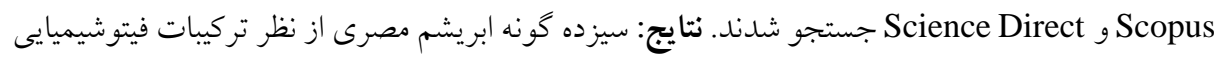

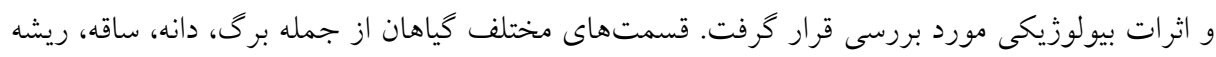

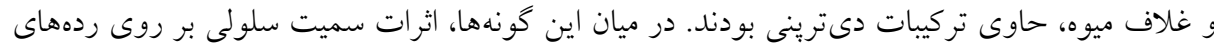

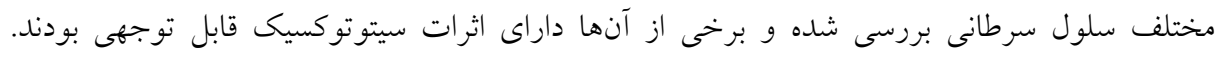

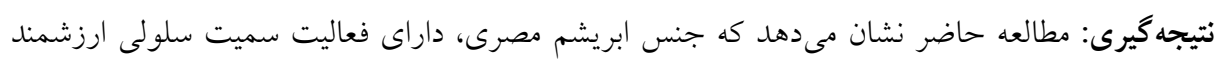

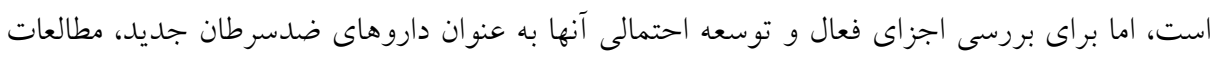

$$
\text { بيشترى لازم است. }
$$

khalighi@imp.ac.ir : نويسنده مسؤول: * تاف

doi: 10.29252/jmp.19.76.1

(C) 2020. Open access. This article is distributed under the terms of the Creative Commons Attribution-NonCommercial 4.0 International License (https://creativecommons.org/licenses/by-nc/4.0/) 